\title{
Spelling Development among Triangle versus Native Bedouin Arabic Pupils
}

\author{
Alon Fragman $^{1, *}$ \\ ${ }^{1}$ Middle Eastern Studies Department, Ben Gurion University, Israel \\ *Correspondence: Middle Eastern Studies Department, Ben Gurion University, Be'er Sheva, Israel. Tel: \\ 972-52-2652-687. E-mail: fragman@bgu.ac.il
}

Received: January 27, $2014 \quad$ Accepted: March 13, 2014 Online Published: April 15, 2014

doi:10.5430/wje.v4n2p65 URL: http://dx.doi.org/10.5430/wje.v4n2p65

\begin{abstract}

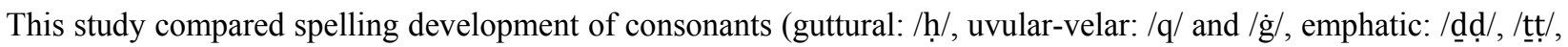
and $/ \widetilde{\partial} I$, and dental: $/ \underline{t} /)$ in the written form of Arabic among native Bedouin Arabic speakers from north and southern Israel $(\mathrm{N}=666)$, versus native Arabic pupils from the triangle $(\mathrm{N}=153)$, learning in second, fourth, and sixth grades. Three tasks were constructed for this study: real word dictation, pseudo-word dictation, and real word recognition. The results show significantly higher scores for spelling among pupils from the triangle versus Bedouin pupils from southern and north Israel in the second grade. Also, Bedouin males from southern Israel scored significantly less than their female counterparts in the group and from all other male pupils who participated in this study at all ages. It is suggested that the gap is unnecessarily gender-oriented, but mainly affected by socio-economic aspects and by the lack of appropriate teacher training for this community.
\end{abstract}

Keywords: bedouin; spelling; native Arabic speakers; gender differences; consonants

\section{Literature Review}

Native Bedouin Arabic speakers are formally Israeli citizens estimated 15\% of Arab Israeli citizens. Approximately $70 \%$ of them live in the Negev and the others live in north Israel, mainly in the Galilee and in Emek Israel.

\subsection{Bedouin Arabic Speakers in Israel}

Being the larger community of the Bedouin minority in Israel, most of the studies had been conducted among the Negev Bedouin sector. These studies showed very low achievements among Bedouin pupils, and the existence of illiteracy to some degree, even in high schools (Ben David, 1994). In addition, higher percentage of dropouts from the educational system had been reported, compared with other native Arabic non-Bedouin teenagers, and compared with the Hebrew sector (Ben Rabi, Amiel, Nijm, \& Dolev, 2009). Other studies focused on mapping the Bedouin dialects (Abdel-Massih and Bahig, 1978; Abu El-Hij'a, 2012; Al-Wer and De Jong, 2009 ; Blanc, 1970; Fischer and Jastrow, 1980; Holes, 1995a; Holes, 1995b; Shawarba, 2007), and specifically the Bedouin dialect of the Galilee in north Israel (Rosenhouse, 1980, 1984, 1995a, 1995b; Rosenhouse and Katz, 1980), and the Bedouin dialects of central and southern Sinai (de Jong, 2011). Also, several studies paid attention to Bedouin dialects outside Israel, for example in Jordan (Palva, 2008), Egypt and eastern Libya (Mitchell, 1960), Iraq (Palva, 2009), and Kuwait (Ayyad, 2011). Additional studies explored sociolinguistic aspects and stylistic variation of the Bedouin dialects of the Negev (Henkin, 1992, 1994, 1996, 1998, 2000, 2005, 2007a, 2007b, 2009a, 2009b, 2010, 2011); Bedouin poetry (Bailey, 1991; Holes and Abu Athera, 2009; Jargy, 1989); anthropological aspects of Bedouin society (Borg, 1999, 2001; Borg and Kressel, 2001); Bedouin manners from sociolinguistic point of view (Piamenta, 1979).

The linguistic characteristics of the Bedouin Arabic dialects were presented in depth by Henkin (1996, 2000, 2011), and also by Rosenhouse (1984). Phonologically, the phoneme /q/ in Bedouin dialects is a voiced /g/, while it is pronounced as $/ \mathrm{k} /, / \mathrm{k} /$, or $/ \mathrm{q} /$ in rural areas, and $/ 1 /$ (glottal stop) in urban dialects. In addition, an aXC sequence in Bedouin dialects is broken by a stressable /a/ (X being a back consonant), e.g. gahwah> gaháwah (coffee).

Preliminary study which explored spelling errors of consonants among native Bedouin Arabic pupils from the Negev (Fragman, 2013) found significant improvement in spelling consonants from the second to the fourth grade. However, 
no improvement had been recorded from the fourth to the sixth grade. In addition, the results indicated significantly lower scores for emphatic phonemes in comparison with other phonemic groups at all elementary grades tested. Further, gender differences were observed with significantly higher scores for female pupils at all elementary ages for all tasks. In order to better understand these findings, and have a wider picture of spelling development among Bedouin population, this study explored spelling development among Bedouin Arabic speakers in north and southern Israel in comparison with other native Arabic speakers (not from Bedouin origin), living in the triangle.

\subsection{Phonetic and Phonological Characteristics of Arabic}

One of the most prominent characteristics of Arabic is its' diglossic nature. Ferguson (1959) have already defined diglossia in the late fifties' of the last century and pointed out to the existence of two different types of language contact systems in Arabic: a written form which is high prestigious standard Arabic, and a spoken form which is a low prestigious non-standard Arabic, both in daily use of all Arabic speakers around the world. The written and the spoken systems significantly differ from one another in vocabulary, and in other aspects of phonology and grammar as well. Although spoken Arabic is the mother language of all native Arabic speakers, it consists of thousands of dialects, which vary widely along geographical, religious and socioeconomic status from one Arabic speaking community to another (Freha, 1989; Holes, 1995a), and therefore it is often looked down upon as not 'real Arabic' (Henkin, 2010). The written system of Arabic (often considered Literary Arabic or called Modern Standard Arabic) is used mainly for formal communication, media, poetry, and prayer. Native Arabic speakers learn the written system of Arabic at elementary school. Therefore, several scholars consider it as a second language (Ayari, 1996; Saiegh-Haddad, 2003), and native Arabic speakers as bilingual (Eviatar \& Ibrahim, 2000). Previous studies have shown that the diglossic nature of Arabic affects linguistic processes, including phonological awareness, reading words and spelling among native Arabic speakers (Abu Rabia \& Taha, 2004; Saiegh-Haddad, 2003, 2004, 2005, 2007). This complicated linguistic situation was also found as the main cause for low reading achievements among Arab-speaking students in Israel in PIRLS 2006 tests (Zuzovsky, 2008).

Arabic orthography also plays major role in the acquisition of the written form of Arabic. The most pertinent to this study will be briefly presented. Arabic orthography is comprised of 29 letters; 26 letters represent consonants, but three additional letters carry a double function and represent consonants at times and long vowels in some cases. Most nouns and all verbs have three to four letter consonantal roots (Berman, 1978). Being differently vowelled and affixed, they form the words of the Arabic lexicon (Ravid \& Schiff, 2006). The final form of a word in the lexicon is defined by patterns, regularly formed by a combination of vowels and other extra consonants, and produce nouns with number and gender (Shimron, 2003).

Another linguistic characteristic in the written system of Arabic are diacritic dots which are obligatory part of 15 letters. These letters in Arabic share identical basic structure. Therefore, they can be distinguished only on the basis of the existence/non-existence of diacritic dots, their location (above or under the letter) and number (none, one, two, or three). Thus, the fact that similar graphemes represent different phonemes, and at the same time different graphemes represent the same phoneme, makes grapheme-phoneme correspondences quite complex in Arabic. In addition, most letters in Arabic are connected to the following letter except for six letters which are never connected to the next letter (They may connect only from the right side). The majority of the letters that are written connected to the following letter vary in shape according to the placement in the word (word-initial, medial, or word-final position).

Several studies in the past few years have pointed out difficulties with the acquisition of the written form of Arabic among native Arabic speakers (Abu Rabia, 2001, 2002; Abu Rabia \& Siegel, 1995; Abu Rabia \& Taha, 2004, 2006; Azzam, 1984, 1993; Bentin \& Ibrahim, 1996; Eviatar, Ibrahim \& Ganayim, 2004; Ibrahim, Eviatar \& Aharon-Perez, 2002; Saiegh-Haddad, 2003, 2004, 2005, 2007; Saiegh-Haddad, Levin, Hende, and Ziv, 2011). For example, it was found that reaction times for visual recognition of Arabic words by senior high school native Arabic skilled readers were longer than reaction times for Hebrew words by native Hebrew high school seniors (Bentin \& Ibrahim, 1996), English words by native English undergraduates, and Serbo-Croatian words by native Serbo-Croatians undergraduates (Frost, Katz, \& Bentin, 1987). It was also found that letter recognition process is faster and more accurate in Hebrew (L2) than in Arabic (L1) among bilingual native Arabic adults (Abu Rabia, 2001). Other studies reported that the reading process in Arabic among native Arabic skilled readers is slower than the reading process in Hebrew among native Hebrew skilled readers (Azzam, 1984, 1993; Ibrahim, Eviatar \& Aharon-Perez, 2002). It was suggested that the complexity of Arabic orthography imposes a linguistic burden that is created by additional orthographic information in Arabic, as compared with other orthographies, such as the Hebrew orthography (Azzam, 1993; Eviatar, Ibrahim, \& Ganayim, 2004; Ibrahim, Eviatar \& Aharon-Perez 2002), and English orthography 
(Eviatar \& Ibrahim, 2004). According to these studies, this linguistic burden of the Arabic orthography plays a significant role in the acquisition of the written form of Arabic, compared with other languages, and may cause a delay in the literary development and in the ability to achieve automatic reading (Ibrahim et al., 2002; Eviatar, Ibrahim, \& Ganayim, 2004; Ibrahim and Aharon-Peretz, 2005). Trying to better understand the linguistic features that affect the reading process in the written form of Arabic, a recent study by Taha, Ibrahim, and Khateb (2013) among adult native Arabic skilled readers found that reaction times variance was higher and accuracy was lower in non-connected words compared with connected words. The researchers suggested that orthographic connectivity in Arabic skilled readers had positive impact on their reading process. In the current study we focused on developmental aspects of spelling of a sample of seven consonants representing all phone-mic groups: guttural: /h/,

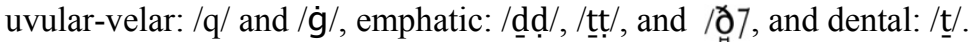

\section{Research Question}

What is the spelling development of guttural (/h/), uvular-velar (/q/and /g $/)$, emphatic (/ddẹ/, /ttt/, and /ö7, and dental (/t $/$ ) consonants in the written form of Arabic among native Bedouin Arabic speakers learning in the second, the fourth, and the sixth grades in north and south Israel versus native Arabic pupils from the triangle?

We may assume that spelling development of consonants will be similar among all native Arabic speakers in the elementary stages, and it is expected that there will be a significant improvement over time. Based on previous studies among native Arabic students (Abu-Rabia \& Siegel, 1995; Abu-Rabia \& Taha, 2004; Saiegh-Haddad, 2003, 2004, 2005, 2007), we hypothesized that native Bedouin speakers, like their counterparts from other Arabic authorities, would make spelling errors, mainly in representing phonemes that do not exist in their L1, or phonemes which sound different in their home vernacular (for example the word /qahwah/ (coffee) is pronounced/gahwah/ by native Bedouin speakers).

\section{Method}

\subsection{Participants}

This study included 658 native Bedouin Arabic pupils from four elementary schools located in four different authorized authorities, learning in the second $(\mathrm{N}=216)$, fourth $(\mathrm{N}=215)$, and sixth $(\mathrm{n}=227)$ grades, boys $(\mathrm{N}=328)$ and girls $(\mathrm{N}=330)$, compared with native Arabic pupils from the triangle $(\mathrm{N}=153)$ learning in the second $(\mathrm{N}=54)$, fourth $(\mathrm{N}=50)$, and the sixth $(\mathrm{N}=49)$ grade, 75 boys and 78 girls. The schools are considered to be of average socio-economic background based on an index determined by the Israeli Central Bureau of Statistics (Central Bureau of Statistic, 2013). Students with learning disabilities of any kind were excluded from the sample.

\section{Measures}

\subsection{Task Construction}

This study included three experimental tasks that were created for this study: real word dictation, pseudo-word dictation, and word recognition (based on Author, 2013).

\subsubsection{Real Word Dictation}

This task comprised of eight real words. Each word included two or three of the phoneme-grapheme consonants targeted. The words were dictated in class by a native Arabic speaker who accompanied the researcher. Each word was dictated three times. A score of 1 or 0 was given based on correct or incorrect spelling for the phonemes targeted only. (Cronbach's alpha: .92)

\subsubsection{Pseudo-Word Dictation}

Similarly to the previous task, the pseudo-word task was comprised of eight pseudo-words. Each word included two or three of the phoneme-grapheme consonants targeted. The pseudo words were created by changing one letter from the real words used in the real word dictation task. For example: /mithqāj/ instead of /mithqāl/ (weigh-scale). The words were read live in class by a native Arabic speaker who accompanied the researcher. Each word was read aloud three times. A score of 1 or 0 was given based on correct or incorrect spelling for the phonemes targeted only. (Cronbach's alpha: .92) 


\subsubsection{Real Word Recognition}

In this task the students were required to recognize correctly spelled words in pairs of words where one word was spelled correctly and the other word was spelled incorrectly as a result of changing one grapheme only, for example /qarya/ - /karya/. This task, which was based on a similar task used by Siegel, Share \& Geva (1995) was comprised of 20 word pairs (Cronbach's Alpha: .84).

\subsection{Procedure}

This study was conducted with the permission of the Ministry of Education Chief Scientist's Office. Data were collected towards the end of the school year by the author in the second, fourth, and sixth grade classrooms. Instructions were given in Arabic, their mother tongue. The order of test administration was altered in order to counterbalance the effects of one task on another. Testing took one full 45 minute lesson.

\section{Results}

This study explored spelling development of consonants in the written form of Arabic among native Bedouin Arabic speakers living in north and south Israel, learning in the second, fourth, and sixth grades, versus native Arabic pupils from the triangle. Specifically, this study focused on guttural (/h/), uvular-velar (/q/and / $\dot{\mathbf{g}} /)$, emphatic (/ddd/, /tt /, and /OJ), and dental (t/t/) consonants. Three tasks were constructed for this study: real word dictation, pseudo-word dicta-tion, and real word recognition. Table 1 shows mean scores for all tasks according to groups and grades.

Table 1. Mean Scores across Group, Grade, and Task

\begin{tabular}{lllll}
\hline & & $\begin{array}{l}\text { Real word } \\
\text { dictation } \\
\text { M (SD) }\end{array}$ & $\begin{array}{l}\text { Pseudo word } \\
\text { dictation } \\
\text { M (SD) }\end{array}$ & $\begin{array}{l}\text { Word } \\
\text { recognition } \\
\text { M (SD) }\end{array}$ \\
\hline \multirow{2}{*}{ Bedouin pupils (north) } & & & & \\
& $2^{\text {nd }}$ grade & $75.15(30.10)$ & $68.92(34.64)$ & $90.98(11.55)$ \\
& $4^{\text {th }}$ grade & $78.88(25.75)$ & $72.95(27.49)$ & $94.65(9.49)$ \\
& $6^{\text {th }}$ grade & $87.09(21.72)$ & $80.38(24.17)$ & $98.45(6.13)$ \\
Bedouin pupils (south) & $2^{\text {nd }}$ grade & $68.28(25.83)$ & $66.88(24.86)$ & $80.39(20.46)$ \\
& $4^{\text {th }}$ grade & $84.11(12.30)$ & $78.43(12.16)$ & $94.32(10.94)$ \\
Native Arabic pupils from & $6^{\text {th }}$ grade & $82.94(21.47)$ & $76.77(21.77)$ & $94.39(15.45)$ \\
& $2^{\text {nd }}$ grade & $88.79(20.46)$ & $91.81(3.13)$ & $93.89(11.70)$ \\
& $4^{\text {th }}$ grade & $90.00(15.77)$ & $85.35(23.18)$ & $97.64(5.44)$ \\
& $6^{\text {th }}$ grade & $91.63(19.90)$ & $85.36(17.11)$ & $99.63(1.42)$ \\
\hline & & & $89.22(19.45)$ & \\
\hline
\end{tabular}

A 3-way repeated measure ANOVA analysis was performed with task as the within-subject factor, and group, and grade as the between-subject factors. Main effect was found for task F $(2,1620)=241.09, p<.001, \eta_{\mathrm{p}}^{2}=.22$, for group $\mathrm{F}(2,810)=20.61, p<.001, \eta_{\mathrm{P}}{ }^{2}=.05$, and for grade $\mathrm{F}(2,810)=19.86, p<.001, \mathrm{\eta}_{\mathrm{P}}{ }^{2}=.05$. In addition, two interactions were found: an interaction between task and group $\mathrm{F}(4,1620)=8.35, p<.001, \mathrm{n}_{\mathrm{P}}{ }^{2}=.02$ and another interaction between group and grade $\mathrm{F}(4,810)=3.42, p=.009, \mathrm{\eta}_{\mathrm{P}}{ }^{2}=.02$. Bonferroni post hoc analyses showed that scores for each task significantly differed. The scores for word recognition task were the highest among participants from all groups, followed by scores for real word task, and pseudo word task respectively. In addition, scores in real word task and pseudo word task among the two Bedouin groups were significantly lower than scores among pupils from the triangle in these tasks. Further, scores for word recognition task were significantly lower among southern Bedouin than scores among pupils from the other groups.

In order to answer the research question, a 3-way repeated measure ANOVA was performed with sound as within-subject factor, and group and grade as the between subject factors. However, due to the high effect for task, it had been decided to conduct this analysis for each task separately. Table 2 shows mean scores for the phonemes targeted for this study across grades and groups in real word task. 
Table 2. Mean Scores for Phonemes across Grades and Groups - Real Word Task

\begin{tabular}{|c|c|c|c|c|}
\hline & & $\begin{array}{l}\text { Bedouin pupils } \\
\text { (north) } \\
\text { M (SD) }\end{array}$ & $\begin{array}{l}\text { Bedouin pupils } \\
\text { (south) } \\
\mathrm{M}(\mathrm{SD})\end{array}$ & $\begin{array}{l}\text { Native Arabic } \\
\text { pupils from } \\
\text { Triangle } \\
\text { M (SD) }\end{array}$ \\
\hline \multirow[t]{3}{*}{ Guttural } & $2^{\text {nd }}$ grade & $85.18(31.39)$ & $87.61(25.84)$ & $95.06(19.86)$ \\
\hline & $4^{\text {th }}$ grade & $92.94(22.59)$ & $98.82(6.18)$ & $96.66(15.43)$ \\
\hline & $6^{\text {th }}$ grade & $96.25(17.83)$ & $95.09(18.68)$ & 95.91 (19.99) \\
\hline \multirow[t]{3}{*}{ Uvular-velar } & $2^{\text {nd }}$ grade & 78.17 (31.97) & $79.52(28.89)$ & $92.28(20.91)$ \\
\hline & $4^{\text {th }}$ grade & $87.66(24.57)$ & $94.24(11.94)$ & $95.66(11.07)$ \\
\hline & $6^{\text {th }}$ grade & $90.81(21.28)$ & $90.31(21.82)$ & $94.21(20.28)$ \\
\hline \multirow[t]{3}{*}{ Emphatic } & $2^{\text {nd }}$ grade & $63.35(36.28)$ & $50.71(29.61)$ & $82.87(24.91)$ \\
\hline & $4^{\text {th }}$ grade & $65.26(35.35)$ & $69.24(23.32)$ & $82.25(26.49)$ \\
\hline & $6^{\text {th }}$ grade & 79.46 (29.99) & $72.77(28.31)$ & $86.98(22.09)$ \\
\hline \multirow[t]{3}{*}{ Dental } & $2^{\text {nd }}$ grade & $78.06(36.39)$ & $73.33(39.05)$ & $91.35(24.38)$ \\
\hline & $4^{\text {th }}$ grade & $86.21(29.60)$ & $88.79(22.97)$ & $92.66(19.38)$ \\
\hline & $6^{\text {th }}$ grade & $90.64(24.05)$ & $83.20(31.76)$ & $90.64(24.05)$ \\
\hline
\end{tabular}

Table 3 shows mean scores for phonemes across grades and groups - pseudo word task.

Table 3. Mean Scores for Phonemes across Groups and Grades - Pseudo Word Task.

\begin{tabular}{lllll}
\hline & & $\begin{array}{l}\text { Bedouin pupils } \\
\text { (north) }\end{array}$ & $\begin{array}{l}\text { Bedouin pupils } \\
\text { (south) }\end{array}$ & $\begin{array}{l}\text { Native Arabic pupils } \\
\text { from Triangle }\end{array}$ \\
& M (SD) & M (SD) & M (SD) \\
\hline \multirow{2}{*}{ Guttural } & $2^{\text {nd }}$ grade & $78.34(37.73)$ & $83.80(28.16)$ & $91.35(26.05)$ \\
& $4^{\text {th }}$ grade & $87.50(27.55)$ & $96.75(9.92)$ & $96.66(15.43)$ \\
Uvular-velar & $6^{\text {th }}$ grade & $90.37(24.98)$ & $92.24(22.24)$ & $94.55(20.80)$ \\
& $2^{\text {nd }}$ grade & $74.07(35.46)$ & $75.87(27.83)$ & $90.53(22.36)$ \\
\multirow{4}{*}{ Emphatic } & $4^{\text {th }}$ grade & $81.08(27.34)$ & $90.85(12.17)$ & $92.88(16.76)$ \\
& $6^{\text {th }}$ grade & $89.67(22.23)$ & $87.68(21.97)$ & $94.33(19.52)$ \\
\multirow{2}{*}{ Dental } & $2^{\text {nd }}$ grade & $55.92(40.12)$ & $48.43(29.08)$ & $78.57(28.53)$ \\
& $4^{\text {th }}$ grade & $57.82(36.61)$ & $53.72(26.60)$ & $70.85(24.82)$ \\
& $6^{\text {th }}$ grade & $64.29(37.69)$ & $57.25(32.06)$ & $81.63(25.08)$ \\
& $2^{\text {nd }}$ grade & $64.67(38.97)$ & $66.03(33.00)$ & $79.62(26.23)$ \\
& $4^{\text {th }}$ grade & $71.79(33.74)$ & $80.53(24.69)$ & $85.33(25.34)$ \\
& $6^{\text {th }}$ grade & $84.19(27.25)$ & $74.16(31.24)$ & $86.39(23.48)$ \\
\hline
\end{tabular}


Table 4 shows mean scores for phonemes across grades and groups - word recognition task.

Table 4. Mean Scores for Phonemes across Groups and Grades - Word Recognition Task

\begin{tabular}{llllc}
\hline & & $\begin{array}{l}\text { Bedouin pupils } \\
\text { (north) }\end{array}$ & $\begin{array}{l}\text { Bedouin pupils } \\
\text { (south) }\end{array}$ & $\begin{array}{l}\text { Native Arabic pupils } \\
\text { from Triangle }\end{array}$ \\
& M (SD) & M (SD) & M (SD) \\
\hline Guttural & $2^{\text {nd }}$ grade & $91.13(14.56)$ & $83.17(21.98)$ & $94.13(10.81)$ \\
& $4^{\text {th }}$ grade & $95.67(8.68)$ & $95.42(11.19)$ & $98.33(6.07)$ \\
Uvular-velar & $6^{\text {th }}$ grade & $98.23(7.30)$ & $94.18(16.75)$ & $100.00(.00)$ \\
& $2^{\text {nd }}$ grade & $87.35(17.97)$ & $77.14(25.26)$ & $93.05(14.90)$ \\
& $4^{\text {th }}$ grade & $92.70(15.56)$ & $89.82(18.18)$ & $94.50(12.66)$ \\
Emphatic & $6^{\text {th }}$ grade & $98.97(4.97)$ & $93.79(18.49)$ & $99.48(3.57)$ \\
& $2^{\text {nd }}$ grade & $91.76(13.89)$ & $79.86(24.79)$ & $94.17(15.07)$ \\
& $4^{\text {th }}$ grade & $95.10(12.15)$ & $95.95(11.20)$ & $98.85(4.86)$ \\
& $6^{\text {th }}$ grade & $98.29(8.38)$ & $94.90(15.02)$ & $99.41(2.85)$ \\
\hline
\end{tabular}

A 3-way repeated measure ANOVA performed for each task found: 1. Main effect for sound - for real word dictation $\mathrm{F}(3,2430)=223.38, p<.001, \eta_{\mathrm{P} 2}=.21$, for pseudo word dictation $\mathrm{F}(3,2427)=327.23, p<.001, \eta_{\mathrm{P} 2}=.28$, and for word recognition task $\mathrm{F}(2,1618)=14.95, p<.001, \eta_{\mathrm{p} 2}=.01$. 2 . Main effect for group - for real word dictation $\mathrm{F}$ $(2,810)=11.10, p<.001, \eta_{\mathrm{P} 2}=.02$, for pseudo word dictation $\mathrm{F}(2,809)=14.37, p<.001, \eta_{\mathrm{P} 2}=.03$, and for word recognition task $\mathrm{F}(2,809)=23.51, p<.001, \eta^{\mathrm{p} 2}=.05$. 3. Main effect for grade - for real word dictation $\mathrm{F}(2,810)=$ $11.10, p<.001, \eta^{\mathrm{P} 2}=.02$, for pseudo word dictation $\mathrm{F}(2,809)=9.18, p<.001, \eta^{\mathrm{p} 2}=.02$, and for word recognition task $\mathrm{F}(2,809)=37.68, p<.001, \mathrm{\eta}_{\mathrm{P} 2}=.08$. 3. Interaction for sound and grade for real word dictation $\mathrm{F}(6,2430)=4.05, p$ $<.001, \eta^{\mathrm{P} 2}=.01$, for pseudo word dictation $\mathrm{F}(6,2427)=4.56, p<.001, \eta^{\mathrm{P} 2}=.01$, and for word recognition task $\mathrm{F}$ $(4,1618)=3.83, p<.001, \eta_{\mathrm{p} 2}=.01$. 4. Interaction for sound and group was found for real word dictation $\mathrm{F}(6,2430)=$ $12.92, p<.001, \eta_{\mathrm{P} 2}=.03$ and for pseudo word dictation $\mathrm{F}(6,2427)=15.06, p<.001, \eta_{\mathrm{P} 2}=.03 .5$. Interaction between group and grade was found for word recognition task $\mathrm{F}(4,809)=5.17, p<.001, \eta^{\mathrm{P} 2}=.02$. Bonferroni post hoc analyses showed that scores for pseudo word task were significantly higher among native Arabic pupils from the triangle versus Bedouin pupils from both groups. It also showed that scores among Bedouin pupils from the south were significantly lower in the second grade from native Arabic pupils from the triangle in real word task and were significantly lower than scores achieved by pupils from both groups for word recognition task. However, it significantly improved from the second to the fourth grade for both real word and word recognition task. Among Bedouin pupils from the north, a significant improvement was recorded from second to sixth grade in both tasks. No significant change was recorded among native Arabic pupils from the triangle in all tasks - They always scored higher than the other two Bedouin groups. Further, it showed that scores for emphatic phonemes were significantly lower from the scores for other phonemes among all groups for pseudo word task, and improved significantly towards the sixth grade. However, it was still higher among native Arabic pupils from the triangle. Also, scores for emphatic phonemes were significantly lower for real word dictation among Bedouin pupils from the north than scores achieved by native Arabic pupils from the triangle. However, it significantly improved from second to fourth grade and from fourth to sixth grade. A significant improvement in spelling accuracy for emphatic phonemes was also found from second to fourth grade for word recognition task. In addition, scores for uvular-velar, emphatic, and dental phonemes were significantly lower for real word dictation among Bedouin pupils from the south than scores among native Arabic pupils from the triangle. However, it significantly improved from second to fourth grade. A significant improvement was also found in guttural phonemes from the second to the fourth grade, and in uvular-velar phoneme from second to fourth grade and from fourth to sixth grade for word recognition task.

In order to find whether gender differences also existed, another set of 3-way repeated measure ANOVA analysis was performed for each task as the within-subject factor, and pupils, grade, and gender as the between-subject factors. Main effect for gender $\mathrm{F}(1,793)=5.91, p=.015, \mathrm{\eta}^{\mathrm{P} 2}=.007$ and an interaction for group and gender $\mathrm{F}(2,793)=6.40$, $p=.002, \eta_{\mathrm{p} 2}=.01$ were found for word recognition task only. Bonferroni post hoc analyses showed that Bedouin males from the south significantly scored lower than females from their group, but also lower than all participants from other groups in this task. 


\section{Discussion}

This study explored spelling development of consonants in the written form of Arabic among native Bedouin Arabic speakers living in north and southern Israel, learning in the second, the fourth, and the sixth grades, versus native Arabic pupils from the triangle. Specifically, this study focused on guttural (/h/), uvular-velar (/q/and $/ \dot{\mathbf{g}} /)$, emphatic

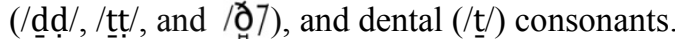

The results of this study support previous studies which found that spelling errors may occur even in the end of elementary school (Hamdan and Amayreh, 2007) as a result of similarity to other phonemes in Arabic or maybe as a result of diglossia, as suggested by Saiegh-Haddad (2003, 2004, 2005, 2007). Specific attention was given in several studies to the difficulty of emphatic phonemes among native Arabic speakers (Abu Rabia \& Siegel, 1995; Abu Rabia \& Taha, 2004, 2006; Amayreh \& Dyson, 1998; Ayari, 1996; Saiegh-Haddad, 2003). These aspects were extensively discussed in these studies.

However, the most prominent result of this study is that scores among Bedouin pupils from the south were significantly lower versus native Arabic speakers from the triangle in the second grade for real word task. Also, scores among Bedouin pupils from the south were significantly lower versus Bedouin pupils from the north and native Arabic speakers from the triangle in the second grade for (real) word recognition task. Further, spelling proficiency of emphatic phonemes was lower among the two Bedouin groups versus their counterparts. Similar scores for all pupils were recorded only in the fourth grade. It should be mentioned that although there is no significant difference between the groups in fourth and sixth grades, the mean score among native Arabic speakers from the triangle was higher in all tasks and grades.

Various studies found different results for the acquisition process of consonants. A study explored the acquisition process of consonants among native Arabic Jordanian children found that all consonants were acquired approximately in the fourth grade at the age of $8 ; 6-9 ; 0$ (Amayreh, 2003), yet full proficiency in the standard form of Arabic was only found at later age, according to another study (Al-Rabaa, 1986). Previous studies among Negev Bedouin sector have also shown low achievements among this population among elementary school pupils and at higher ages in various fields. For example, in the "Meitzav" tests in Arabic for the 2005-06 school year, fifth and eighth grade pupils among the Bedouin communities had significantly lower achievements comparing with their counterparts from the same grades in the Arab school system as a whole (Rudnitzky, 2012). The existence of illiteracy to some degree in Bedouin high schools had been also previously reported (Ben David, 1994). Another study which explored Bedouin social needs found high percentage of dropouts from the educational system, mainly in the higher grades (Ben Rabi, Amiel, Nijm, \& Dolev, 2009), mostly for economic distress (Rudnitzky, 2012) . However, the results of this study show that the gap between Bedouin population, mainly from southern Israel, and their counterparts from the triangle begins at an early age, probably before elementary school. Explanations for this result may vary; it may be attributed to general educational, social and economic aspects of the Bedouin society (Ben David, 1994). In a survey conducted between 2003-2005 among the Bedouin population of northern Israel, Ben Rabi, Amiel, Nijm, \& Dolev (2009) found that forty percent of the mothers had no education at all. They also reported low percentage of participation among children in organized after-school activities. According to The Galilee Society Survey 2007 (The Galilee Society, Rikaz \& Al-Ahali, 2008), while approximately 15\% of the general Arab population do not attend school, it had been reported that one-fourth of those aged 34 and over in the Bedouin sector had never attended school. Taking into consideration the high rates of unemployment among this population, and that the average family has six to seven children, the Bedouin constitute one of the poorest communities in Israel. Ben Rabi, Amiel, Nijm, \& Dolev (2009) suggested that all this has broad implications for the economic and social well-being of Bedouin children. The results of this study hinder that this situation of the Bedouin community may also affect the literary readiness of children from this sector for second language acquisition (the written form of Arabic) at the very beginning of elementary school.

Another possible explanation may be attributed to teacher training. Natural growth of the Bedouin population led to growth in the educational system in recent years as well (Ben David, 1994). However, surveys and statistical data report the lack of professionally trained local teachers (Abu-Rubiyya, al-Athauna, \& al-Bador, 2012). Apparently, some of the teachers lack sufficient educational knowledge, and they are unauthorized (Rodnitzky 2012). Also, percentage of Bedouin students studying at universities in Israel is estimated $4.6 \%$ of all Arab students for all degrees, based on figures for the 2005-06 academic year (ibid), and the number of college graduates (mostly from The Kaye College of Education) is unstable (Abu Bader \& Gradus, 2010), and certainly not enough to meet the needs of the Bedouin population (Abu-Saad, 1995). Further, a substantial part of the teachers is not local, working in the Bedouin Educational system temporarily only (Abu-Rubiyya, al-Athauna, \& al-Bador, 2012; Abu Bader \& Gradus, 2010). 
They are required by the Ministry of Education and Culture to spend the first few years of their teaching in Bedouin schools in the southern district. However, after only a few years of teaching experience, it seems that they do not actually acclimatized in the southern Bedouin community, and they prefer to return to their villages in the north. This ongoing situation causes a high rate of teacher turnover (Abu-Rubiyya, al-Athauna, \& al-Bador, 2012). Also, cultural differences and differences in the spoken dialect (north/south Bedouin) affect teacher-pupil relationship, and pupils' motivation for learning (Abu Bader \& Gradus, 2010). It is possible that this entire complicated situation affects educational quality (Abu Ras, 2012) and has an impact already during the initial stages of learning the written form of Arabic.

Also, specific attention should be given to male pupils from southern Bedouin sector that scored lower not only from female pupils but also from males from the other groups (extended discussion regarding male-female spelling proficiency differences can be found in: Author, 2013; Mohamed, Elbert, \& Landerl, 2011). It suggests that the gap is unnecessarily gender-oriented, but as discussed above - mainly sectorial, affected by social and financial aspects and at the same time, by the lack of appropriate teacher training and educational supportive environment for the Bedouin community, mainly in southern Israel.

\section{Conclusions}

Being the first study explored spelling development among Bedouin society versus native Arabic speakers in other sectors in Israel in elementary school, it should be taken into serious consideration by policy makers, inspectors, school managers and teachers to give their full attention to the initial stages of teaching the written form of Arabic at the beginning of elementary school, and probably in much earlier stages. This, in order to provide Bedouin pupils with solid foundation of the written form of Arabic, as a basis for more equal opportunity in advanced education at later stages.

\section{References}

Abdel-Massih, E. T., \& Bahig, A. F. (1978). A Comprehensive Study of Egyptian Arabic. Ann Arbor : Center for Near Eastern and North African Studies, University of Michigan.

Abu Bader, S., \& Gradus, Y. (2010). The Negev Bedouin: Statistical Data Book. Ben Gurion University of the Negev.

Abu El-Hij'a, D. (2012). Facebook written Levantine vernacular languages. The Levantine Review, 1(1), 68-105.

Abu Rabia, S., \& Taha, H. (2004). Reading and spelling error of native Arabic dyslexic readers. Reading and Writing: An Interdisciplinary Journal, 17(7-8), 651-689. http://dx.doi.org/10.1007/s11145-004-2657-x

Abu Rabia, S., \& Taha, H. (2006). Phonological errors predominate in Arabic spelling across grades 1 - 9. Journal of Psycholinguistic Research, 35(2), 167-188. http://dx.doi.org/10.1007/s10936-005-9010-7

Abu Ras, T. (2012). The Bedouin population in the Negev: transformations in an era of urbanization. Jerusalem: The Abraham Fund Initiatives.

Abu Sa'ad, I. (1995). Bedouin Arab education in the context of radical social change: what is the future? Compare: $a$ Journal of Comparative and International Education, 25(2), 149-160.

Abu-Rabia, S. (2001). The role of vowels in reading Semitic scripts: Data from Arabic and Hebrew. Reading and Writing: An Interdisciplinary Journal, 14(1-2), 39-59. http://dx.doi.org/10.1023/A:1008147606320

Abu-Rabia, S. (2002). Reading in a root-based morphology language. Journal of Research in Reading, 25(3), 299-309. http://dx.doi.org/10.1111/1467-9817.00177

Abu-Rabia, S., \& Siegel, L. S. (1995). Different orthographies, different context effects: The effects of Arabic sentence context on skilled and poor readers. Reading Psychology, 16(1), 1-19. http://dx.doi.org/10.1080/0270271950160101

Abu-Rubiyya, S., Al-Athauna, F., \& Al-Bador, S. (1996). Survey of Bedouin Schools in the Negev. The Ford Foundation and the Reformed Churches in the Netherlands. Retrieved from http://adva.org/uploaded/SURVEY\%20OF\%20BEDOUIN\%20SCHOOLS\%20IN\%20THE\%20NEGEV.pdf (last checked 2.10.2013).

Al-Rabaa, S. (1986). Diglossia in the classroom: the Arabic case. Anthropological Linguistics, 28, 73-79. 
Al-Wer, E., \& De Jong, R. (2009). Arabic Dialectology. Leiden: Brill. http://dx.doi.org/10.1163/ej.9789004172128.i-298

Amayreh, M. M. (2003). Completion of the consonant inventory of Arabic. Journal of Speech, Language, and Hearing Research, 46(3), 517-529. http://dx.doi.org/10.1044/1092-4388(2003/042)

Amayreh, M.M., \& Dyson, A. T. (1998). The acquisition of Arabic consonants. Journal of Speech, Language, and Hearing Research, 41(3), 642-653.

Ayari, S. (1996). Diglossia and illiteracy in the Arab world. Language Culture and Curriculum, 9(3), 243-253. http://dx.doi.org/10.1080/07908319609525233

Ayyad, H. S. (2011). Phonological development of typically developing Kuwaiti Arabic-speaking preschoolers. PhD thesis, Columbia: The University of British Columbia.

Azzam, R. (1984). Orthography and reading of the Arabic language. In J. Aaron and R.M. Joshi (Eds.), Reading and writing disorders in different orthographic systems (pp. 1-29). Kluwer Academic Publishers.

Azzam, R. (1993). The nature of Arabic reading and spelling errors of young children. Reading and Writing: An Interdisciplinary Journal, 5(4), 355-385. http://dx.doi.org/10.1007/BF01043112

Bailey, C. (1991). Bedouin Poetry from Sinai and the Negev: Mirror of a Culture. Oxford: Clarendon Press.

Ben Rabi, D., Amiel, S., Nijim, F., \& Dolev, T. (2009). Bedouin children in the Negev: Characteristics, needs and patterns of service use. Jerusalem: Myers-JDC-Brookdale Institute.

Ben-David, J. (1994). The Bedouin education system in the Negev: Reality and need to promote it. Jerusalem: Floersheimer Institute for Policy Studies (Hebrew).

Bentin, S., \& Ibrahim, R. (1996). New evidence for phonological processing during visual word recognition: The case of Arabic. Journal of Experimental Psychology, 22(2), 309-323.

Berman, R.A. (1978). Modern Hebrew Structure. Tel Aviv: Israel: University Publishing.

Blanc, H. (1970). The Arabic Dialect of the Negev Bedouins. Jerusalem: Israel Academy of sciences and Humanities.

Borg, A. (1999). The color categories of the Negev Bedouin. In A. Borg (Ed.), The Language of Color in the Meditterenean (pp. 121-147). Stockholm: Almkvist/Wiksell.

Borg, A. (2001). Encoding the boundary between the secular and the sacred: a phonological note on the prophet's name in the dialect of the Negev and Sinai Bedouin. In . J. Rosenhouse and A. Elad-Bouskila (Eds.), Linguistic and Cultural Studies on Arabic and Hebrew (pp. 49-59). Wiesbaden: Harrassowitz Verlag.

Borg, A., \& Kressel, G. M. (2001). Bedouin in the Negev personal names and Sinai. Zeitschrift für arabische Linguistik, 40(1), 32-70.

Central Bureau of Statistics. (2013). Israel. (last checked 2.10.2013). http://www1.cbs.gov.il/reader/newhodaot/hodaa_template.html?hodaa=201211106

De Jong, R. E. (2011). A Grammar of the Bedouin Dialects of Central and Southern Sinai. Leiden: Brill. http://dx.doi.org/10.1163/ej.9789004201019.i-440

Eviatar, Z., \& Ibrahim, R. (2000). Bilingual is as bilingual does: Metalinguistic abilities of Arab-speaking children. Applied Psycholinguistics, 21(4), 451-471. http://dx.doi.org/10.1017/S0142716400004021

Eviatar, Z., \& Ibrahim, R. (2004). Morphological and orthographic effects on hemispheric processing of nonwords: A cross-linguistic comparison. Reading and Writing: An Interdisciplinary Journal, 17(7-8), 691-705. http://dx.doi.org/10.1007/s11145-004-2659-8

Eviatar, Z., Ibrahim, R., \& Ganayim, D. (2004). Orthography and the Hemispheres: Visual and Linguistic Aspects. Neuropsychology, 18(1), 174-184. http://dx.doi.org/10.1037/0894-4105.18.1.174

Ferguson, C. A. (1959). Diglossia. Word, 15, 325-340.

Fischer, W., \& Jastrow, O. (1980). Handbook of Oriental Studies. Leiden: Brill.

Fragman, A. (2013). Spelling accuracy of consonants in Arabic among Negev Bedouin students. Online Journal of Modern Languages, 3(4), 330-336.

Freha, A. (1989). Al-lahjāt waOsloob Dirasatiha (The Dialects and the Methods of Studying them). Beirut: Dar Aljeel. (Arabic). 
Frost, R., Katz, L., \& Bentin, S. (1987). Strategies for visual word recognition and orthographical depth: A multilingual comparison. Journal of Experimental Psychology: Human Perception and Performance, 13(1), 104-114. http://dx.doi.org/10.1037/0096-1523.13.1.104

Hamdan, J.M., \& Amayreh, M. M. (2007). Consonant profile of Arabic-speaking school-age children in Jordan. Folia Phoniatr Logop, 59(2), 55-64. http://dx.doi.org/10.1159/000098338

Henkin, R. (1992). The three faces of the Arabic participle in Negev Bedouin dialects: continuous, resultative, and evidential. Bulletin of the school of Oriental and African Studies, 55(3), 433-444. http://dx.doi.org/10.1017/S0041977X00003633

Henkin, R. (1994). On the narrative imperative in Negev Arabic and Russian. Journal of Semitic studies, 39(2), 245-283. http://dx.doi.org/10.1093/jss/XXXIX.2.245

Henkin, R. (1996). Negev Bedouin vs. sedentary Palestinian narrative style. In S. Isre'el, I. Singer, \& R. Zadok (Eds.), Israel Oriental Studies XVI, Studies in Modern Semitic Languages (pp. 169-192). Leiden: Brill.

Henkin, R. (1998). Narrative Styles of Palestinian Bedouin Adults and Children. Pragmatics, 8(1), 47-78.

Henkin, R. (2000). Narrative styles of Negev Bedouin men and women. Oriente Moderno, 19(1), 59-81.

Henkin, R. (2005). Task-related variation in tense usage in Arabic-Hebrew interlanguage. In D. Diskin-Ravid, \& H. Bat-Zeev Shyldkrot (Eds.), Perspectives on Language and Language Development (pp. 393-405). Kluwer Academic Publishers. http://dx.doi.org/10.1007/1-4020-7911-7_28

Henkin, R. (2007a). Negev Arabic. Encyclopedia of Arabic Language and Linguistics, 3, 360-369. Leiden: Brill Academic Publishers.

Henkin, R. (2007b). Swaying on the scale from standard to sound when writing non-written dialects. In T. Bar, \& E. Cohen (Eds.), Studies in Semitic and General Linguistics in Honor of Gideon Goldenberg (pp. 45-73). Münster: Alter Orient und Altes Testament Band 334.

Henkin, R. (2009a). How Interdialectal is Peripheral Oral Bedouin Poetry?. In G. Goldenberg, \& A. Shisha-Halevy (Eds.), Egyptian, Semitic and General Grammar: Workshop in Memory of H. J. Polotsky (pp. 239-269). Jerusalem: The Israel Academy of Sciences and Humanities.

Henkin, R. (2009b). The cognate curse in Negev Arabic: from playful punning to coexistence conflicts. Israel Studies in Language and Society, 2(2), 169-206.

Henkin, R. (2010). Negev Arabic: dialectal, sociolinguistic, and stylistic variation. Semitica Viva Series. Wiesbaden: Otto Harrassowitz.

Henkin, R. (2011). Hebrew and Arabic asymmetric contact in Israel. Lodz Papers in Pragmatics, 7(1), $61-100$.

Holes, C. (1995a). Modern Arabic: Structures, functions, and varieties. London: Longman.

Holes, C. (1995b). Community, dialect and urbanization in the Arabic-speaking Middle East. Bulletin of the School of Oriental and African Studies, 58(2), 270-287. http://dx.doi.org/10.1017/S0041977X00010764

Holes, C., \& Athera, S. S. (2009). Poetry and Politics in Contemporary Bedouin Society. Ithaca Press.

Ibrahim, R., \& Aharon-Peretz, J. (2005). Is literary Arabic a second language for native Arab speakers?: Evidence from a semantic priming study. The Journal of Psycholinguistic Research, 34(1), 51-70. http://dx.doi.org/10.1007/s10936-005-3631-8

Ibrahim, R., Eviatar, Z., \& Aharon Peretz, J. (2002). The characteristics of the Arabic orthography slow its cognitive processing. Neuropsychology, 16(3), 322-326. http://dx.doi.org/10.1037/0894-4105.16.3.322

Jargy, S. (1989). Sung Poetry in the oral tradition of the Gulf region and the Arabian Peninsula. Oral Tradition, 4(1-2), 174-188.

Mitchell, T. M. (1960). Prominance and syllabication in Arabic. Bulletin of the School of Oriental and African Studies, 23(2), 369-389. http://dx.doi.org/10.1017/S0041977X00149997

Mohamed, W., Elbert, T., \& Landerl, K. (2011). The development of reading and spelling abilities in the first 3 years of learning Arabic. Reading and Writing: An Interdisciplinary Journal, 24(9), 1043-1060. http://dx.doi.org/10.1007/s11145-010-9249-8

Palva, H. (2008). Sedentary and Bedouin dialects in contact: remarks on Karaki and Salti (Jordan). Journal of Arabic and Islamic Studies, 8(1), 53-70. 
Palva, H. (2009). From qəltu to gələt: diachronic notes on linguistic adaptation in Muslim Baghdad Arabic. In E. Al-Wer and R. E. de Jong (Eds.), Arab Dialectology: In Honor of Clive Holes on the Occasion of His Sixtieth Birthday (pp. 17-40). Leiden: Brill. http://dx.doi.org/10.1163/ej.9789004172128.i-298.12

Piamenta, M. (1979). The linguistic system of the Negev Bedouion manners and its linguistic description. In S. Pines, M.J. Kister, S. Shaked and J. Blau (Eds.), Studia orientalia: memoriae D. H. Baneth dedicata (pp. 125-173). Jerusalem: Magnes Publishers.

Ravid, D., \& Schiff, R. (2006). Roots and patterns in Hebrew language development: evidence from written morphological analogies. Reading and Writing: An Interdisciplinary Journal, 19(8), 789-818. http://dx.doi.org/10.1007/s11145-006-9004-3

Rosenhouse, J. (1980). The dialects of Shibli and 'Aramsha in the Galilee. In J. Rosenhouse (Ed.), Texts in the dialects of Bedouins in Israel. Occasional Papers on the Middle East 3 (pp. 6-49). Haifa: The University of Haifa.

Rosenhouse, J. (1984). The Bedouin Dialects. Wiesbaden: Otto Harrassowitz.

Rosenhouse, J. (1995a). An Arabic Bedouin story and its linguistic analysis. Zeitschrift für arabische Linguistik, 30, $62-83$.

Rosenhouse, J. (1995b). Features of intonation in Bedouin Arabic narratives of the Galilee (North Israel). In T. Harviainen and A. Parpola (Eds.), Dialectologia Arabica: A Collection of Articles in Honor of the sixtieth Birthday of Professor H. Palva, Studia Orientalia, Vol. 75 (pp. 193-215). Helsinky: Finnish Oriental society.

Rosenhouse, J., \& Katz, J. (1980). Texts in Bedouin dialects in Israel. Haifa: Haifa University.

Rudnitzky, A. (2012). The Bedouin population in the Negev: social, demographic and economic factors. Jerusalem: The Abraham Fund Initiatives.

Saiegh-Haddad, E. (2003). Linguistic distance and initial reading acquisition: the case of Arabic diglossia. Applied Psycholinguistics, 24(3), 431 - 451. http://dx.doi.org/10.1017/S0142716403000225

Saiegh-Haddad, E. (2004). The impact of phonemic and lexical distance on the phonological analysis of words and pseudowords in a diglossic context. Applied Psycholinguistics, 25(4), 495-12. http://dx.doi.org/10.1017/S0142716404001249

Saiegh-Haddad, E. (2005). Correlates of reading fluency in Arabic: diglossic and orthographic factors. Reading and Writing: An Interdisciplinary Journal, 18(6), 559 - 582. http://dx.doi.org/10.1007/s11145-005-3180-4

Saiegh-Haddad, E. (2007). Linguistic constraints on children's ability phonemes in Arabic. Applied Psycholinguistics, 28(4), 607 - 626. http://dx.doi.org/10.1017/S0142716407070336

Saiegh-Haddad, E., Levin, I., Hende, N., \& Ziv, M. (2011). The linguistic affiliation constraint and phoneme recognition in diglossic Arabic. Journal of Child Language, 38(2), 297-315. http://dx.doi.org/10.1017/S0305000909990365

Shawarbah, M. (2007). The Bedouin Dialect of the Tiyaha in the Negev: phonology, morphology, and some selected syntactic issues. PhD thesis. Jerusalem: Hebrew University. (Hebrew).

Shimron, J. (2003). Semitic languages: Are they really root-based?. In J. Shimron (Ed.), Language Processing and Acquisition in Languages of Semitic, Root-Based, Morphology (pp. 1-28). Amsterdam: Benjamins. http://dx.doi.org/10.1075/lald.28.01shi

Taha, H., Ibrahim, R., \& Khateb, A. (2013). How does Arabic orthographic connectivity modulate brain activity during visual word recognition: an ERP study. Brain Topography, 26(5), 292-302. http://dx.doi.org/10.1007/s10548-012-0241-2

The Galilee Society, Rikaz \& Al-Ahali. (2008). The Palestinians in Israel: Social-Economic Survey 2007 - Major Findings. Shfar'am (Arabic and English).

Zuzovsky, R. (2008). Capturing the dynamics behind the narrowing achievement gap between Hebrew-speaking and Arab-speaking schools in Israel: findings from TIMSS 1999 and 2003. Educational Research and Evaluation, 14(1), 47-71. http://dx.doi.org/10.1080/13803610801896562 